Review Article

\title{
Research Highlights on the Evolution of Precambrian Crust of Peninsular India: Constraints from Recent Zircon U-Pb Geochronological Results
}

\author{
Y J BHASKAR RAO*, NAMRATA KHADKE and T VIJAYA KUMAR \\ LAM-MC-ICPMS Facility, CSIR-National Geophysical Research Institute, Hyderabad, India
}

(Received on 05 June 2016; Accepted on 20 June 2016)

\begin{abstract}
During the last quadrennial period, (2012-2016), many aspects of the Precambrian geology of the Indian peninsula were revisited by Indian geoscientists and their collaborators with the advantage of modern analytical techniques for geochronology as well as new perspectives on global geodynamics in space and time. Important contributions were made to the Archean and Proterozoic geological evolution of the Dharwar, Singhbhum, Bundelkhand and Bastar cratons, the granulite gneiss terrains, especially the Southern Granulite Terrain (SGT) and the Eastern Ghats Granulite Terrain (EGGT) and also the Proterozoic sedimentary Basins of peninsular India. Significantly, these studies have provided evidence for Paleo- to Eoarchean crustal remnants apart from placing precise age constraints on geological events. Most authors favoured the interpretation of Archean geodynamics in a plate tectonics conceptual framework for the assembly of Indian terranes in the supercontinent reconstructions, as reviewed on the basis of a short compilation of published research articles.
\end{abstract}

Keywords: Precambrian Crustal Evolution; Peninsular India; Geochronology; U-Pb Zircon Ages

\section{Introduction}

Unravelling the geodynamic processes that underpin the formation, destruction and stabilization of Earth's continental crust in deep-time is fundamental to geosciences. Precambrian $(>0.5 \mathrm{Ga})$ geodynamics has gained immensely from advancements in analytical technology relevant to radiometric age determination, especially, the in-situ U-Th-Pb dating of accessory minerals like zircon $\left(\mathrm{ZrSiO}_{4}\right)$ at a high spatial resolution, typically $<50 \mu \mathrm{m}$. The last quadrennial period witnessed a proliferation of precise age and isotopic data constraining the chronology of magmatism, metamorphism and deformation of many Precambrian rock units in peninsular India. New in-situ zircon U$\mathrm{Pb}$ ages along with ${ }^{177} \mathrm{Hf} /{ }^{176} \mathrm{Hf}$ isotopic data and in many cases zircon trace element compositions have been obtained, using the Secondary Ionisation Mass Spectrometry (SIMS), the Laser AblationMulticollector Inductively Coupled Plasma Mass Spectrometry (LA-MC-ICPMS) and LA-Quadruple ICPMS (LA-QICPMS). Peninsular India (here excluding the Himalayan region described elsewhere in this volume) presents one of the largest exposures of Precambrian crust in the world. Salient geological features of the region are summarised in Fig. 1 and reviewed by, among others, Naqvi (2005), Ramakrishnan and Vaidyanadhan (2008), Sharma (2009), Valdiya (2010), Sarkar and Gupta (2012). The Indian shield is made up of 5 cratons, viz., Dharwar, Bastar, Singhbhum, Bundelkhand and Aravalli cratons. These cratons are Archean granite-greenstone terrains that consist predominantly of low- to mediummetamorphic grade rock associations including: 1) grey gneisses, mostly Tonalite-TrondhjemiteGranodiorite (TTG) gneisses, 2) variably migmatised belts and rafts of metavolcanic and metasedimentary rocks, the greenstone belts and 3) intrusives; granitoids ranging in age from Mesoarchean to Mesoproterozoic, mafic dyke swarms, and variety of ultramafic to mafic bodies including kimberlites and lamproites. The Indian cratons are bordered by Proterozoic fold belts or 'mobile belts' that occur singularly or in pairs between the cratons. Also, the Proterozoic sedimentary Basins preserve upto a few kilometres thick supracrustal rock successions

\footnotetext{
*Author for Correspondence: E-mail: yjbhaskarrao@gmail.com
} 


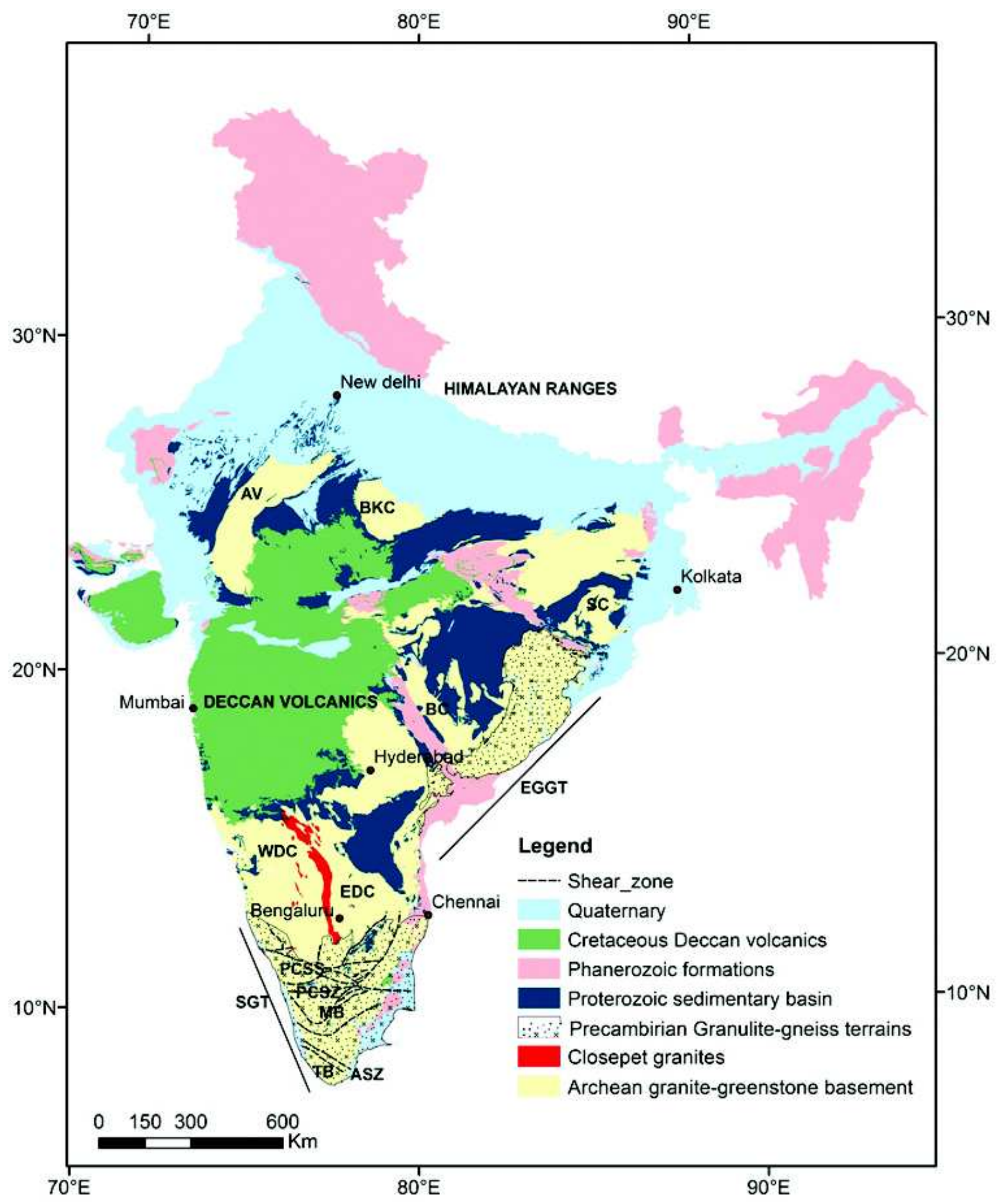

Fig. 1: Simplified geology of Peninsular India modified after Geological Survey of India (1996). Major Precambrian structural/ tectonic elements include Western Dharwar Craton-(WDC), Eastern Dharwar Craton-(EDC), Bastar Craton-(BC), Singhbhum Craton-(SC), Bundelkhand Craton-(BKC), Aravalli fold Belt-(AV), Southern Granulite Terrain-(SGT), Madurai Block-(MB), Trivandrum Block-(TB), Palghat Cauvery Shear System-(PCSS), Palghat Cauvery Shear Zone(PCSZ), Achankovil Shear Zone-(ASZ), Eastern Ghat Granulite Belt-(EGGT). See text for more information 
deposited in diverse facies and environments. Together, the rock units in these tectonic domains record a geologic history spanning $\sim 3.0$ billion years from $\sim 3.5$ to $0.5 \mathrm{Ga}$. Important contributions to the geochronology of these terranes are summarised and discussed briefly in the context of some current and emerging views on global geodynamics, outlined below.

It is well known that the Earth was formed around $4.567 \mathrm{Ga}$ (Giga aeons) ago, and in its earliest stages witnessed dramatic events such as the giant impacts, magma ocean, core-formation and largescale mantle differentiation and the formation of primordial crust (for a review see Harrison et al., 2009). A definite answer to the question; when did the earliest terrestrial crust form? remains elusive largely because of its poor preservation owing to factors such as rapid recycling because of the possible destruction of the early crust in asthenospheric convection and heavy bombardment' event during the late Hadean $(>4.0 \mathrm{Ga})$. In this regard, the Indian peninsula has also been a target in the search for early continental crust vis-a-vis the oldest crustal components found in some parts of the world. The oldest dated rock on Earth is $\sim 4.030$ Ga old, from the Acasta gneiss complex, Slave craton, Canada (Mojzsis et al., 2014 for a review). However, the most valuable source of information on the Hadean Eon comes from a few hundred detrital zircon grains that have been dated upto $\sim 4.4 \mathrm{Ga}$ by high resolution $\mathrm{U}-\mathrm{Pb}$ dating methods, mainly using the Sensitive High Resolution Ion Microprobe-SHRIMP (e.g., Wilde et al., 2001). Most of these zircons are from a quartzite at Jack Hills, Mt. Narryer, Western Australia. A smaller population of Hadean zircons are sourced from Acasta gneiss and 4.08 Ga inherited zircon cores from an $\sim 3.83 \mathrm{Ga}$ granodiorite gneiss from Akilia Islands, west Greenland and a few Eoarchean TTG gneiss suites such as the Itsaq gneiss, west Greenland, the SaglekHebron gneiss complex, Labrador and the Anshan gneiss, North China craton and some supracrustal rocks that are tectonically interleaved in the Eoarchean gneisses, e.g., the Nuvvuagittuq belt, Quebec, Canada (Collerson et al., 1991; Nutman et al., 1996; Mojzsis and Harrison, 2002; O'Neil et al., 2007; Harrison, 2009). Although the origin of these Hadean zircons remains equivocal, many authors believe that they represent Hadean continental crust. Search for Paleo- and Eoarchean remnants in southern India have been partially successful as described below.

It is now widely appreciated that as much as $73 \%$ of the Earth's continental crust was extracted from the mantle by the end of the Archean (Belousova et al., 2010; Dhuime et al., 2012; Cawood et al., 2013) and major events in the accretion of Archean juvenile crust centred around $3.0 \mathrm{Ga}$ and $2.7 \mathrm{Ga}$ (Condie et al., 2000; Voice et al., 2011). However, the nature of the geodynamic process during the Archean remains controversial. The common question; when did plate tectonics begin on Earth? remains enigmatic. Many researchers favour a view that the late Paleoarchean/early Mesoarchean ( $c a$. 3.3 to $3.0 \mathrm{Ga}$ ) marked a transition in the planet's geodynamic regime from a dominantly vertical (driven by mantle upwelling) towards dominantly horizontal (Phanerozoic-style plate tectonics) and that some form of plate tectonics operated since at least ca. $3.2 \mathrm{Ga}$ (e.g., O'Neil et al., 2007; Condie and Kröner, 2008; Arndt, 2013). However, others have argued that modern style plate tectonics did not begin on Earth until the Neoproterozoic (Bedard et al., 2013 and references therein). It is also postulated that the Archean accretionary orogens comprise a special category of 'ultra hot' orogens (Chardon et al., 2011; Gerya, 2014 and references therein). Archean plate tectonic regimes may therefore be distinct compared to Phanerozoic plate tectonics on several counts, although many authors now believe that Archean plate tectonic regimes may not have been very different from the Phanerozoic plate tectonics. Such considerations provide a useful framework in which to interpret geological, geophysical and geochronological data on Archean cratons, research on the Indian cratons being no exception.

\section{Growing evidence for Eoarchean (4.0-3.6 Ga) to Paleoarchean (3.6-3.2 Ga) Crust from Peninsular India}

Many recent studies have documented new zircon $\mathrm{U}-\mathrm{Pb}$ geochronological data mainly on the Dharwar and Singhbhum cratons together with new geological, petrological and geochemical information. These studies attest to the wide spread occurrence of MesoNeoarchean gneiss and greenstone units in all the cratons of peninsular India, apart from localized evidence for Eo-Paleoarchean zircons. In the Western 
Dharwar Craton (WDC), Jayananda et al. (2015) showed that much of the cratonic core in the southwestern part records two major periods of crust generation; ca. 3350-3280 Ma and 3230-3200 Ma. During these intervals, TTG accretion was penecontemporaneous with greenstone volcanism and sedimentation. During the earlier phase, both highand low- $\mathrm{Al}_{2} \mathrm{O}_{3}$ TTG magmas were emplaced. Their derivation involved melting of shallow and deep island arc-type crust that may have formed during the Eoarchean to Paleoarchean as indicated by their bulk geochemistry and $\mathrm{Sm}-\mathrm{Nd}\left(\mathrm{T}_{\mathrm{DM}}\right)$ and zircon Lu-Hf model ages for the TTG suites. The EoarcheanPaleoarchean context is also reflected by detrital (magmatic) zircons extracted from metasediments deposited between $\sim 3.3$ and $2.7 \mathrm{Ga}$ as well as from modern stream sediments (Bhaskar Rao et al., 2008, Maibam et al., 2016; Lancaster et al., 2014; Santosh et al., 2014, 2015, 2016; Sarma et al., 2014; Hokada et al., 2013). The interpretations are also consistent with wholerock Sm-Nd isotopic systematics and model ages (Jayananda et al., 2015; De et al., 2015 for review). An interesting suggestion has been that the Coorg block, along the south-western margin of the WDC (Fig. 1) may comprise the oldest as well as an exotic terrane in southern India (Santosh et al., 2014, $2015,2016)$. This is based on new age data on both meta-igneous rocks (granitoids, diorites, charnockites and volcanic flows) related to ancient arc magmatism and metasedimentary rocks (quartzite, ferruginous quartzite, banded iron formation-BIF, and calcareous/ pellitic schists) considered as inter-arc shelf and pelagic accretionary packages. The igneous suites include multiple magmatic events around 3.5, 3.2, 2.7 and 2.5-2.4 Ga, while zircons from the metasediments include multiple discrete populations between 3.4 and $1.3 \mathrm{Ga} . \varepsilon_{\mathrm{Hf}}$ and $\mathrm{T}_{\mathrm{DM}}^{\mathrm{C}}$ model ages of the $\sim 3.5$ and 3.2 Ga magmatic zircons from the Coorg rocks indicate both juvenile and recycled crustal precursors of EoMesoarchean ancestry, upto $3.7 \mathrm{Ga}$. A detrital zircon grain from a ferruginous quartzite sample yielded $\mathrm{Hf}$ $\mathrm{T}_{\mathrm{DM}}^{\mathrm{C}}$ age of $4031 \mathrm{Ma}$, an indication of a Neohadean protolith in the provenance of the EoarcheanMesoarchean metasediments (Santosh et al., 2014). This result and the view that the Coorg may be an exotic block in southern India warrant further study with more data.

The geochronology of the Singhbhum craton also received considerable attention in terms of the antiquity of the Archean crustal components. The major crustal units of the craton include greenschist- to amphibolitefacies supracrustals of the Older Metamorphic Group $(\mathrm{OMG})$, tonalite of the Older Metamorphic Tonalite Gneisses (OMTG), Tonalitie-Granite suites of the Singhbhum Granite (SG) batholith and the greenschist facies platformal sediments, mainly Banded Iron Formations interlayered with mafic and felsic volcanic rocks of the Iron Ore Group (IOG) (Mukhopadhyay et al., 2008). Zircons from TTGs of the OMTG and SG (Phases I, II, and III) reveal a polycyclic evolution of the Archean crust (Upadhyay et al., 2014). These authors showed that the tonalite and trondhjemite of the OMTG were emplaced at ca. 3.45-3.44 Ga together with Phase III of the Singhbhum Granite pluton, while granite of the OMTG were emplaced at ca. 3.35-3.32 together with Phase I and Phase II of the Singhbhum Granite pluton. These record an early phase of relatively high-grade metamorphism at 3.30$3.28 \mathrm{Ga}$ followed by fluid-induced alteration during low-grade metamorphism at 3.19-3.12 Ga, and 3.02$2.96 \mathrm{Ga}$, apart from the $c a .2 .52 \mathrm{Ga}$ and $1.06 \mathrm{Ga}$ metamorphic events recorded along the North Singhbhum Mobile Belt and the Singhbhum shear zone at the northern margin of the craton. The zircon grains in granites have inherited cores with ages of $c a .3 .61$ $\mathrm{Ga}$ and 3.46-3.41 Ga related to Eoarchean crust forming events. Nelson et al. (2014) reported new age data for detrital (igneous) zircons from metasedimentary enclaves, which constrain the regional deformation and amphibolite-facies metamorphism to the interval between 3325 and 3000 Ma. They summarised that (1) between 3530 and $3300 \mathrm{Ma}$, tonalite were emplaced, with volcanic, clastic and carbonate rocks and banded iron-formation (cycle 1) deposited onto tonalitic basement until 3375 Ma; (2) between 3325 and 3300 Ma, burial, deformation and uplift transformed the central part of the Singhbhum basement to tonalite gneisses, with cycle 1 sedimentary rocks incorporated into the gneisses as enclaves but preserved within synforms around the basement margins; post-3.3 Ga regional metamorphism, granodiorite intrusives were emplaced until ca. $3285 \mathrm{Ma}$; (3) BIF and clastic sedimentary rocks (cycle 2) were deposited around the margins of the craton onto the older (cycle 1) sedimentary rocks and adjacent gneissic basement until $c a$. 3.1 $\mathrm{Ga}$; (4) a further episode of granite intrusion at 3090 Ma was followed by uplift and erosion of the central 
part of the craton prior to $2806 \mathrm{Ma}$; (5) volcanosedimentary and banded iron-formation rocks were deposited during a third sedimentary cycle at $c a .2 .8$ $\mathrm{Ga}$.

Several studies focused on the Eastern Dharwar Craton (EDC) with the objective of deciphering the chronostratigraphy of the greenstone belts and establishing the chronology of granite gneiss and granitoid components (Anand et al., 2014; Jayananda et al., 2015; Maibam et al., 2015, 2016; Tushipokla and Jayananda, 2013; Ram Mohan et al., 2014; Yang and Santosh, 2015; Hokada et al., 2013). Newer geochronology data are likely to appear in near future to throw further light on the pertinent petrogenetic problems.

Paleoproterozoic and Neoproterozoic cryptic sutures and ophiolites from the Southern Granulite Terrain (SGT), with its different crustal blocks characterised by distinct structural and age specrtra attracted considerable international attention, where, in many cases, existing geological models were revised in the light of new geochronological data. U-Pb zircon ages and Sm-Nd depleted mantle model ages $\left(\mathrm{T}_{\mathrm{DM}}\right)$ of charnockites, associated migmatites and metasedimentary rocks and a limited dataset of zircon $\mathrm{Lu}$-Hf isotopic data point to a complex genetic history for the charnockites in the SGT (e.g., Tomson et al., 2013; Brandt et al., 2014; Kröner et al., 2012; Plavsa et al., 2012, 2014; Peucat et al., 2013; Glorie et al., 2014; Bhattacharya et al., 2014; Taylor et al., 2015., Vijaya Kumar et al., 2016). For instance, the Sm -Nd $\mathrm{T}_{\mathrm{DM}}$ age data suggest involvement of ancient crustal components (up to $\sim 3.2 \mathrm{Ga}$ ) in the genesis of the Proterozoic charnockites from the Madurai and Trivandrum Blocks (Plavsa et al., 2012; Tomson et $a l ., 2013$ and references therein). This has prompted a considerable curiosity on: 1) the proportion and distribution of Proterozoic ortho-gneisses with juvenile magmatic precursors in the SGT (Kröner et al., 2012, 2015; Taylor et al., 2015; Vijaya Kumar et al., 2016) and 2) tectonic scenarios for the multiple episodes of felsic magmatism responsible for crust formation and recycling during the $\sim 2$ billion year geologic record represented in the SGT south of the PCSZ. In this regard, an interesting observation has been that the Trivandrum and Nagercoil blocks include vast stretches of charnockite gneisses whose protoliths represent Paleoproterozoic juvenile magmatism at
2.1-1.85 Ga (Kröner et al., 2012; 2015 and Vijaya Kumar et al., 2016).

It was long known that the northern limit of the SGT marks an unbroken prograde metamorphic transition from amphibolite to granulite grade. Further south, the N-S trending structural fabrics of the Dharwar craton have been reworked by the E-W trending mylonitic fabric of the crustal-scale shear zone system, the Palghat-Cauvery Shear System (PCSS), also referred to as the Cauvery Shear Zone (CSZ). In recent years, the tectonic evolution of the PCSS has been resolved broadly into two temporal components, Palaeoproterozoic and Neoproterozoic (spanning the Ediacaran-Cambrian), rather than a single late Neoproterozoic-early Cambrian deformation event inferred in the earlier studies. For instance, around the Moyar-Salem-Attur shear zone at the northern limit of the PCSS, Neoarchean (3.0$2.5 \mathrm{Ga}$ ) basement protoliths were shown to be affected by the granulite facies metamorphism during the early Paleoproterozic ca. 2.5-2.48 Ga, (Anderson et al., 2012; Brandt et al., 2014; Mohan et al., 2013; Glorie et al., 2014; Plavsa et al., 2015). In this northern part of the PCSS, many authors interpreted the shear zone systems as cryptic sutures and described several suprasubduction suites including the layered meta-anorthosite and related rock suites of Sittampundi, Bhavani and Gobichettipalayam and other ultramafic-mafic bodies around Attapadi, Kanjamalai and Wynad, considered by some workers as dismembered Paleoproterozoic ophiolite complexes (Yellappa et al., 2012; Santosh et al., 2012, 2013b; Mohan et al., 2013; Collins et al., 2014b; Praveen et al., 2014; Yang et al., 2016). Subsequent retrogression along shear zones associated with metamorphic-fluid channelling to amphibolite and lower grade gneisses has generally been constrained to between $\sim 740$ and $500 \mathrm{Ma}$. At this time frame, the SGT is generally perceived as a key segment of the Gondwana forming orogens such as the Himalayan-scale collisional orogen, the East African Orogen-EAO (Fig. 2) that lay across the continents of Africa, Greater India (parts of Madagascar, Seychelles, India, Sri Lanka) and Antarctica during the Ediacaran-Cambrian, ca.600$480 \mathrm{Ma}$ (Collins and Pisarevsky, 2005; Fritz et al., 2013 and Collins et al., 2014; Plavsa et al., 2015). In this model, the closure of the Mozambique Ocean and the collision of the Indian (Dharwar) and East African/Madagascan cratonic domains is believed to 
have occurred along the Palghat-Cauvery Shear Zone (PCSZ), in the southern part of the PCSS. Thus, while the deformation in the dextral Moyar-Salem-Attur shear zone of the PCSS is early Paleoproterozoic in age, the PCSZ with dip-slip dextral transpression and north side-up motion has been constrained to $c a$.740$550 \mathrm{Ma}$. The northern part of the Madurai block may have been deformed in four deformational events, and three of which were contemporaneous to the deformation along the PCSZ and associated with High Pressure -Ultra High Temperature metamorphism and deformation between $\sim 550$ and $500 \mathrm{Ma}$, interpreted as the collisional orogeny of the southern margin of the Azania microcontinent marking the closure of the Mozambique ocean (Santosh et al., 2012; Collins et al., 2014b; Plavsa et al., 2015).

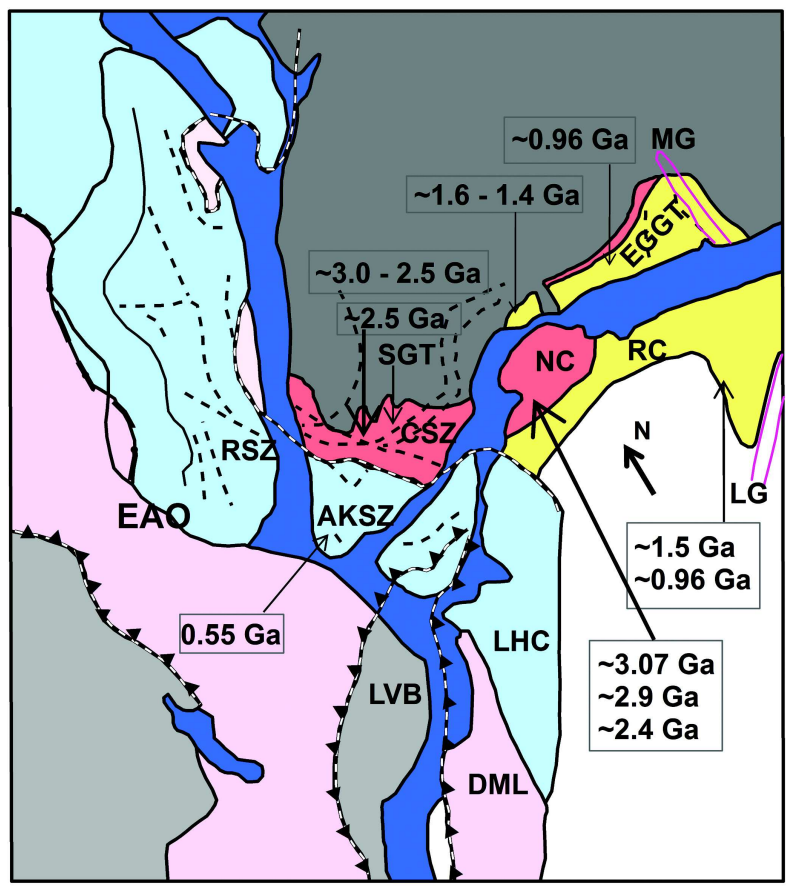

East African Orogen (EAO)

$0.55 \mathrm{Ga}$ Age of metamorphism

Fig. 2: A schematic of correlation of SGT and EGGT with Grenvillean age and Pan-African mobile belts in $\mathrm{E}$. Gondwana (modified after Collins and Windley, 2002). AKSZ-Achankovil Shear Zone, CSZ-Cauvery Shear Zone, DML-Dronning Maud Land, EGGTEastern Ghats Granulite Terrain, LG-Lambert Graben, LHC-Lutzow-Holm Complex, MG-Mahanadi Graben, NC-Napier Complex, RC-Rayner Complex, SGT-Souhern Granulite Terrain, RSZ-Ranotsara Shear Zone, LVB-Lurio-Vijayan Block

\section{Ultra-high temperature (UHT) metamorphism in the EGGT and SGT}

Both in the SGT and EGGT, several localities with UHT $\left(\mathrm{T}>900^{\circ} \mathrm{C}\right)$ metamorphic assemblages are known on a regional scale. During the last quadrennial period, a few detailed studies attempted to link the PT-t evolution of the UHT rocks to the geodynamic processes. In general, source of heat needed for UHT metamorphic conditions on a regional scale has been a subject of debate (see review by Harley, 2016). One view has been that the UHT may record closure and thickening of continental back-arc basins that are characterized by domains of thinned lithosphere. High mantle heat flow prior to orogenesis and thickening of the hot crust could provide the heat source, while a likely tectonic setting for the back-arc inversion is continental accretion and collision of magmatic arcs. A second view relates the UHT to high radioactive heat production in the crustal column (with higher than average content of heat producing elements; U, Th, and $\mathrm{K}$ ) involved in a collisional orogeny and crustal thickening. Clark et al. (2015) studied UHT conditions in the SGT in relation to the tectonics of amalgamation of the Gondwana. New zircon and monazite ages were presented and linked to the petrological evolution based on phase equilibria in the Madurai Block. These authors concluded that the duration of the high- to ultrahigh- temperature metamorphism lasted for $c a$. $40 \mathrm{Ma}$ with peak conditions achieved $c a$. $60 \mathrm{Ma}$ after the formation of an orogenic plateau related to the collision of the microcontinent Azania with East Africa at $c a .610 \mathrm{Ma}$. Similar studies in the EGGT reaffirm an interval between $1130 \mathrm{Ma}$ and $930 \mathrm{Ma}$ corresponding to a single prograde peak and retrograde metamorphic P-T-t evolution trajectory characterised by nearly isobaric cooling from peak UHT conditions to lower solidi (Korhonen et al., 2013). Petrogenesis of the charnockites and enderbites is consistent with their emplacement into hot, subsolidus crust at $c a$. $980 \mathrm{Ma}$. Final melt crystallization at 950 Ma suggests maintenance of subsolidus conditions in the crust for about $30 \mathrm{Ma}$ (Korhonen et al., 2013; Clark et al., 2013 unpbl. field guide of Intl. Conference on Granulites and Granulites, Hyderabad).

\section{Proterozoic magmatism in Peninsular India}

An important development relates to the establishment of ${ }^{207} \mathrm{~Pb} /{ }^{206} \mathrm{~Pb}$ baddeleyite Thermal Extraction Thermal Ionization Mass Spectrometer method for 
high precision age determination of mafic rocks at CSIR-NGRI (Kumar et al., 2014). Combined with Paleomagnetic and geochemical data, the new baddeleyite age data have contributed to the resolution of emplacement ages of mafic dykes from Dharwar, Bastar, Bundelkhand and Singhbhum cratons. For instance, the identification of giant radial dyke swarm emplaced at $\sim 2367 \mathrm{Ma}$ and $\sim 2082 \mathrm{Ma}$ with implications for Paleoproterozoic continental reconstructions and basin evolution (Kumar et al., 2012, 2015; Shankar et al., 2014). Several other researchers have provided new ages, geochemical and paleomagnetic data on the multiple generations of the mafic dyke swarms (e.g., Dash et al., 2013), Proterozoic gabbro-anorthosite plutons (e.g., Kaur et al., 2013; Dharma Rao et al., 2012; Koizumi et al., 2014; Raith et al., 2014), alkaline complexes, kimberlites and lamproites (e.g., Chalapathi Rao et al., 2014; Santosh et al., 2014; Karmalkar et al., 2014; Hippe et al., 2016; He et al., 2015) and a host of granitoid plutons and felsic volcanism (e.g., Ashwal et al., 2013; Dharma Rao et al., 2012, 2013; Meert et al., 2013; Ravikant et al., 2014) from the different tectonic provinces of peninsular India.

\section{Chronostratigraphy, Provenance and Tectonic Evolution of Purana Basins}

Numerous Proterozoic sedimentary basins, well known as Purana Basins overlie the $\geq 2.5$ Ga Archean crystalline basement in all the cratons of India. These basins comprise thick cyclic successions of psammitic, pelitic and calcareous sedimentary formations, locally associated with mafic and felsic volcanic units. During this quadrennial period there has been a spurt in detrital zircon geochronological studies of major sedimentary formations of the Purana Basins of India (e.g., Basu and Bickford, 2014; Turner et al., 2014; Collins et al., 2015; Joy et al., 2015) along with some Re-Os dating of black shale (Tripathy et al., 2013), wholerock Pb$\mathrm{Pb}$ dating of carbonates (Gopalan et al., 2013 and Rai et al., 2015) and $\mathrm{Pb}-\mathrm{Pb}$ baddeleyite and zircon dating of thermal events (mafic dyke swarms, Kumar, 2015 and granites, Ravikant et al., 2014) adjacent to these basins. The data help in constraining the chronology of opening and closing of sedimentation in many Basins and an increased confidence in their chronostratigraphy and correlations thereof. For example, as summarised by Basu and Bickford (2014), the Cuddapah Basin opened shortly before $c a .1900$
Ma, while Ravikant et al. 2014; Kumar et al. 2015 opine that this basin formed at about $2000 \mathrm{Ma}$ ago. The Vindhyan Basin opened before $c a$. 1630 Ma, the Khariar Basin likely opened around $c a .1500 \mathrm{Ma}$ and the Chhattisgarh Basin opened around ca. $1400 \mathrm{Ma}$. The Marwar Basin opened after ca. $750 \mathrm{Ma}$. The Chhattisgarh Basin began to invert at ca. $1000 \mathrm{Ma}$ and closed shortly thereafter. The Indravati and the Vindhyan Basins closed around ca. 1000 Ma. Collins et al. (2015) presented new U-Pb detrital zircon ages along with Hf-isotopic compositions and ${ }^{39} \mathrm{Ar}-{ }^{40} \mathrm{Ar}$ white mica ages for different Formations in the Cuddapah-Kurnool Basin and inferred provenances for the different stratigraphic Groups. The Papaghni and lower Chitravati Groups were sourced from the Dharwar Craton, the Nallamalai Group was constrained to be deposited between $1659 \pm 22 \mathrm{Ma}$ and $\sim 1590 \mathrm{Ma}$, sourced from the Krishna Orogen and the Ongole domain to the east of the Cuddapah Basin and temporally correlatable to the Somanpalli Group of the Pranhita-Godavari Valley Basin (Amarasinghe et al., 2014 for comparison). The Srisailam Formation also correlates with the Nallamalai Group and is possibly sourced from within the basin. The Kurnool Group was deposited during the Neoproterozoic and sourced from the Dharwar craton. The Gandikota Formation is traditionally considered a part of the Chitravati Group. However, the new detrital zircon ages indicate that this Formation may have been deposited much later, after $1181 \pm 29 \mathrm{Ma}$ and possibly correlates with the Kurnool Group. Thus, the new data support linking of depositional events in these probable syn-orogenic foreland basins to their orogenic hinterland and fill-in a 'missing-link' in the tectonic development of the peninsular India.

A study of detrital zircon geochronology and zircon Hf-isotopic compositions in the Upper Vindhyan and Marwar Basins (Turner et al., 2014) indicated that these basins share some similar source regions, mostly from the Aravalli Supergroup, but may have distinct evolutionary histories. The deposition of the Upper Vindhyan sequence closed toward the end of the Mesoproterozoic ( 1000 Ma), whereas deposition in the Marwar Basin was confined to the Ediacaran Cambrian interval ( 570-521 Ma). Turner et al. (2014) concluded that the Purana Basins of India formed during distinct intervals of Precambrian time, viz. the Paleo-Mesoproterozoic, Mesoproterozoic and 
Ediacaran-Cambrian. The formation of these sedimentary basins may be related to tectonics during formation of the supercontinents of Columbia (Lower Vindhyan), Rodinia (Upper Vindhyan) and Gondwana (Marwar). The sedimentary sequences in the Marwar Basin may be part of a large trans-Gondwana series of basins that include the nearby Salt Range (Pakistan), Huqf Supergroup (Oman) and Molo Group (Madagascar).

\section{Age of Ore Deposits}

Beyond the well known regional framework of mineral deposits and mineral provinces, future mineral exploration would depend critically on the acquisition of further data and the integration on the stratigraphic, structural and tectonic controls with geophysical, geochemical, geochronological and isotopic data. This is because the linkage between deposit type and plate margin processes is being increasingly appreciated, for instance, orogenic gold, volcanic-hosted massive sulphide, Mississippi valley type $\mathrm{Pb}-\mathrm{Zn}$ deposits etc., which correlate well with supercontinent cycle and continental assembly. Detailed age and isotopic studies on the Indian ore deposits is gaining momentum, some recent examples include: 1) Pb Sequential Leaching (PbSL dating) of U-mineralised Vempalle dolomites, Cuddapah Basin, which suggested that sedimentation and syn-diagenetic U-mineralization occurred in a short interval between $2000 \mathrm{Ma}$ and $1900 \mathrm{Ma}$ (Rai et al., 2015); 2) U-Th-Pb monazite dating of the Rampura-Agucha and Rajpura-Dariba metamorphosed $\mathrm{Zn}-\mathrm{Pb}$ deposits, Aravalli Belt, NW India indicating Mesoproterozoic mineralization and variations in Neoproterozoic metamorphism (Hazarika et al., 2013); 3) wholerock Sm-Nd age of $3125 \pm 120$ Ma for the Nuggihalli chromite deposit (Mukherjee

\section{References}

Amarasinghe U, Chaudhuri A, Collins A S, Deb G and PatranabisDeb S (2015) Evolving provenance in the Proterozoic Pranhita-Godavari Basin, India Geosci Front 6 453-463

Anand R, Balakrishnan S, Kooijman E and Mezger K (2014) Neoarchean crustal growth by accretionary processes: Evidence from combined zircon-titanite $\mathrm{U}-\mathrm{Pb}$ isotope studies on granitoid rocks around the Hutti greenstone belt, eastern Dharwar Craton, India J Asian Earth Sci 79 $72-85$ et al., 2012); 4) Paleontological detrital zircon U-Pb age constraint of $980 \mathrm{Ma}$ for the Birmania phosphate deposit marking a new episode of phosphogenesis in NW India and a paleogeographic affinity between India and South China (Hughes et al., 2015).

\section{An Outlook}

Although by no means complete or exhaustive enough, this short review brings to fore the sustained interest, national and international, on the evolution of the Precambrian crust of peninsular India. Also the rigor of research in this area is on the rise and this can be ascribed to a greater access to modern laboratory facilities encompassing many more researchers. It is expected that the coming years would witness more significant contributions to the Precambrian geology and geochronology of peninsular India, propelled by the setting up of new laboratories as National facilities as well as the ongoing support to enhance the existing laboratories and research funding in the country by the various Government of India ministries and funding agencies such as; UGC, DST, MoES, CSIR. This is an opportune time for designing and executing major (collaborative) research projects in geochronology and related aspects of Precambrian crustal evolution in India.

\section{Acknowledgment}

YJB's work is supported by the Raja Ramanna Fellowship from the Department of Atomic Energy. We acknowledge help from S. Dinesh Kumar, M. Sirisha and Soumendra Nayak with figure drafting using GIS. Dr. Vadlamani Ravikant and an anonymous reviewer are thanked for their critical reviews and suggestions. We thank the Director, CSIR-NGRI for support.

Anderson J R, Payne J L, Kelsey D E, Hand M and A S Collins M S (2012) High-pressure granulites at the dawn of the Proterozoic Geology 40 431-434

Arndt N (2013) The Formation and Evolution of the Continental Crust Geochemical Perspectives 2 405-533

Ashwal L D, Solanki A M, Pandit M K, Corfu F, Hendriks B W H, Burke K and Torsvik T H (2013) Geochronology and geochemistry of Neoproterozoic Mt. Abu granitoids, NW India: Regional correlation and implications for Rodinia paleogeography Precambrian Res 236 265-281 
Awasthi N, Ray J S, Laskar A H and Yadava M G (2013) Chronology of major terrace forming events in the Andaman Islands during the last $40 \mathrm{kyr} J$ Geol Soc India 82 59-66

Basak K and Ghosh S (2015) Rb-Sr isotopic dating and metamorphism of a suite of migmatite and granites from Sandmata Granulite complex, Rajasthan: An evidence of mesoproterozoic thermal event J Geol Soc India $\mathbf{8 6} 579$ 596

Basu A and Bickford M E (2015) An alternate perspective on the opening and closing of the intracratonic Purana basins in peninsular India J Geol Soc India 85 5-25

Basu A and Bickford M E (2014) Contributions of zircon U-Pb geochronology to understanding the volcanic and sedimentary history of some Purana basins, India J Asian Earth Sci 91 252-262

Bédard J H, Harris L B and Thurston P C (2013) The hunting of the snArc Precambrian Res 229 20-48

Belica M E, Piispa E J, Meert J G, Pesonen L J, Plado J, Pandit M K, Kamenov G D and Celestino M (2014) Paleoproterozoic mafic dyke swarms from the Dharwar craton; paleomagnetic poles for India from 2.37 to $1.88 \mathrm{Ga}$ and rethinking the Columbia supercontinent Precambrian Res 244 100-122

Belousova E A, Kostitsyn Y A, Griffin W L, Begg G C, O'Reilly S Y and Pearson N J (2010) The growth of the continental crust: Constraints from zircon Hf-isotope data Lithos 119 457-466

Bhaskar Rao Y, Griffin W, Ketchum J, Pearson N, Beyer E and chaean Western Dharwar craton, from zircon in situ $\mathrm{U}-\mathrm{Pb}$ dating and Hf-isotopic compositions. Geochim. Cosmochim Acta Suppl 7281

Bhattacharya S, Santosh M, Zhang Z, Huang H, Banerjee A, George P M and Sajeev K (2014) Imprints of Archean to Neoproterozoic crustal processes in the Madurai Block, Southern India J Asian Earth Sci 88 1-10

Bhowmik S K, Wilde S A, Bhandari A, Pal T and Pant N C (2012) Growth of the Greater Indian Landmass and its assembly in Rodinia: Geochronological evidence from the Central Indian Tectonic Zone Gondwana Res 22 54-72

Bickford M E, Saha D, Schieber J, Kamenov G, Russell A and Basu A (2013) New U-Pb ages of zircons in the Owk Shale (Kurnool Group) with reflections on proterozoic porcellanites in India J Geol Soc India 82 207-216

Bora S, Kumar S, Yi K, Kim N and Lee T H (2013) Geochemistry and U-Pb SHRIMP zircon chronology of granitoids and microgranular enclaves from Jhirgadandi Pluton of Mahakoshal Belt, Central India Tectonic Zone, India $J$ Asian Earth Sci 70-71 99-114
Brandt S, Raith M M, Schenk V, Sengupta P, Srikantappa C and Gerdes A (2014) Crustal evolution of the Southern Granulite Terrane, south India: New geochronological and geochemical data for felsic orthogneisses and granites Precambrian Res 246 91-122

Cawood P A, Hawkesworth C J and Dhuime B (2013) The continental record and the generation of continental crust. GSA Bulletin; January/February 2013125 14-32

Chalapathi Rao N V, Kumar A, Sahoo S, Dongre A N and Talukdar D (2014a) Petrology and petrogenesis of Mesoproterozoic lamproites from the Ramadugu field, NW margin of the Cuddapah basin, Eastern Dharwar craton, southern India Lithos 196-197 150 -168

Chalapathi Rao N V, Srivastava R K, Sinha A K and Ravikant V (2014b) Petrogenesis of Kerguelen mantle plume-linked Early Cretaceous ultrapotassic intrusive rocks from the Gondwana sedimentary basins, Damodar Valley, Eastern India Earth-Science Rev 136 96-120

Chardon D, Jayananda M and Peucat J J (2011) Lateral constrictional flow of hot orogenic crust: Insights from the Neoarchean of south India, geological and geophysical implications for orogenic plateaux Geochemistry Geophys Geosystems 12

Chatterjee P, De S, Ranaivoson M, Mazumder R and Arima M (2013) A review of the $\sim 1600$ Ma sedimentation, volcanism, and tectono-thermal events in the Singhbhum craton, Eastern India Geosci Front 4 277-287

Chattopadhyay S, Upadhyay D, Nanda J K, Mezger K, Pruseth K L and Berndt J (2015) Proto-India was a part of Rodinia: Evidence from Grenville-age suturing of the Eastern Ghats Province with the Paleoarchean Singhbhum Craton Precambrian Res 266 506-529

Clark C, Healy D, Johnson T, Collins A S, Taylor R J, Santosh M and Timms N E (2015) Hot orogens and supercontinent amalgamation: A Gondwanan example from southern India Gondwana Res 28 1310-1328

Collerson K D, Campbell L M, Weaver B L and Palacz Z A (1991) Evidence for extreme mantle fractionation in early Archaean ultramafic rocks from northern Labrador Nature $35456-58$

Collins A S, Clark C and Plavsa D (2014) Peninsular India in Gondwana: The tectonothermal evolution of the Southern Granulite Terrain and its Gondwanan counterparts Gondwana Res 25 190-203

Collins A S, Patranabis-Deb S, Alexander E, Bertram C N, Falster G M, Gore R J, Mackintosh J, Dhang P C, Saha D, Payne J L, Jourdan F, Backe G, Halverson G P and Wade B P (2015) Detrital mineral age, radiogenic isotopic stratigraphy 
and tectonic significance of the Cuddapah Basin, India Gondwana Res 28 1294-1309

Collins A S and Pisarevsky S A (2005) Amalgamating eastern Gondwana: The evolution of the Circum-Indian Orogens Earth-Science Rev 71 229-270

Condie K C (2005) Earth as an Evolving Planetary System Elsevier

Condie K C (2000) Episodic continental growth models: Afterthoughts and extensions Tectonophysics 322153 162

Das S, Shukla D, Bhattacharjee S and Mitra S K (2015) Age constraints of Udayagiri Domain of Nellore Schist Belt by Xenotime dating around Pamuru, Prakasam district, Andhra Pradesh J Geol Soc India $\mathbf{8 5}$ 289-298

Das S K (2015) Characteristics of zircon of Chhatrapur beach placer deposit, Ganjam District, Odisha J Geol Soc India $86383-390$

Dash J K, Pradhan S K, Bhutani R, Balakrishnan S, Chandrasekaran G and Basavaiah N (2013) Paleomagnetism of ca. 2.3Ga mafic dyke swarms in the northeastern Southern Granulite Terrain, India: Constraints on the position and extent of Dharwar craton in the Paleoproterozoic Precambrian Res 228 164-176

De Wall H, Pandit M K and Chauhan N K (2012) Paleosol occurrences along the Archean-Proterozoic contact in the Aravalli craton, NW India Precambrian Res 216-219 120131

De S, Mazumder R, Ohta T, Hegner E, Yamada K, Bhattacharyya T, Chiarenzelli J, Altermann W and Arima M (2015) Geochemical and $\mathrm{Sm}-\mathrm{Nd}$ isotopic characteristics of the Late Archaean-Palaeoproterozoic Dhanjori and Chaibasa metasedimentary rocks, Singhbhum craton, E. India: Implications for provenance, and contemporary basin tectonics Precambrian Res 256 62-78

Dey S, Nandy J, Choudhary A K, Liu Y and Zong K (2014) Origin and evolution of granitoids associated with the Kadiri greenstone belt, eastern Dharwar craton: A history of orogenic to anorogenic magmatism Precambrian Res $\mathbf{2 4 6}$ 64-90

Dharma Rao C V, Santosh M and Dong Y (2012) U-Pb zircon chronology of the Pangidi-Kondapalle layered intrusion, Eastern Ghats belt, India: Constraints on Mesoproterozoic arc magmatism in a convergent margin setting $J$ Asian Earth Sci 49 362-375

Dharma Rao C V, Santosh M, Kim S W and Li S (2013a) Arc magmatism in the Delhi Fold Belt: SHRIMP U-Pb zircon ages of granitoids and implications for Neoproterozoic convergent margin tectonics in NW India J Asian Earth Sci 78 83-99
Dharma Rao C V, Santosh M, Sajeev K and Windley B F (2013b) Chromite-silicate chemistry of the Neoarchean Sittampundi Complex, southern India: Implications for subductionrelated arc magmatism Precambrian Res 227 259-275

Dharma Rao C V, Santosh M, Zhang Z and Tsunogae T (2013c) Mesoproterozoic arc magmatism in SE India: Petrology, zircon $\mathrm{U}-\mathrm{Pb}$ geochronology and $\mathrm{Hf}$ isotopes of the Bopudi felsic suite from Eastern Ghats Belt J Asian Earth Sci 75 183-201

Dhuime B, Hawkesworth C J, Cawood P A and Storey C D (2012) A Change in the Geodynamics of Continental Growth 3 Billion Years Ago Science 80-335 1334-1336

Fei G, Zhou X, Duo J, Zhou Y, Wen C Q, Wen Q, He Y, Huo Y, Yang Z, Zhang J and Liu H (2015) Zircon U-Pb age and geochemical characteristics of ore-bearing granodiorite porphyry in the Duobuza porphyry copper deposit, Tibet J Geol Soc India 86 223-232

Fritz H, Abdelsalam M, Ali KA, Bingen B, Collins A S, Fowler A R, Ghebreab W, Hauzenberger C A, Johnson P R, Kusky T M, Macey P, Muhongo S, Stern R J and Viola G (2013) Orogen styles in the East African Orogen: A review of the Neoproterozoic to Cambrian tectonic evolution J African Earth Sci 86 65-106

Gerya T (2014) Precambrian geodynamics: Concepts and models Gondwana Res 25442 -463

Glorie S, De Grave J, Singh T, Payne J L and Collins A S (2014) Crustal root of the Eastern Dharwar Craton: Zircon U-Pb age and Lu-Hf isotopic evolution of the East Salem Block, southeast India Precambrian Res 249 229-246

Gopalan K, Kumar A, Kumar S and Vijaya Gopal B (2013) Depositional history of the Upper Vindhyan succession, central India: Time constraints from $\mathrm{Pb}-\mathrm{Pb}$ isochron ages of its carbonate components Precambrian Res 233 108117

Gupta S, Jayananda M and Fareeduddin (2014) Tourmaline from the Archean G.R.Halli gold deposit, Chitradurga greenstone belt, Dharwar craton (India): Implications for the gold metallogeny Geosci Front 5 877-892

Harrison T M (2009) The Hadean Crust: Evidence from >4 Ga Zircons Annu Rev Earth Planet Sci 37 479-505

Hazarika P, Upadhyay D and Mishra B (2013) Contrasting geochronological evolution of the Rajpura-Dariba and Rampura-Agucha metamorphosed $\mathrm{Zn}-\mathrm{Pb}$ deposit, Aravalli-Delhi Belt, India J Asian Earth Sci 73 429-439

He X F, Santosh M, Zhang Z M, Tsunogae T, Chetty T R K, Ram Mohan M and Anbazhagan S (2015) Shonkinites from Salem, southern India: Implications for Cryogenian alkaline magmatism in rift-related setting $J$ Asian Earth $S c i$ 


\section{$113812-825$}

Henderson B, Collins A S, Payne J, Forbes C and Saha D (2014) Geologically constraining India in Columbia: The age, isotopic provenance and geochemistry of the protoliths of the Ongole Domain, Southern Eastern Ghats, India Gondwana Res 26 888-906

Hippe K, Miller A, von Quadt A, Peytcheva I and Hammerschmidt K (2016) Zircon geochronology of the Koraput alkaline complex: Insights from combined geochemical and U-Pb-Hf isotope analyses, and implications for the timing of alkaline magmatism in the Eastern Ghats Belt, India Gondwana Res 34 205-220

Hokada T, Horie K, Satish-Kumar M, Ueno Y, Nasheeth A, Mishima K and Shiraishi K (2013) An appraisal of Archaean supracrustal sequences in Chitradurga Schist Belt, Western Dharwar Craton, Southern India Precambrian Res 227 99-119

Hughes N C, Myrow P M, McKenzie N R, Xiao S, Banerjee D M, Stockli D F and Tang Q (2015) Age and implications of the phosphatic Birmania Formation, Rajasthan, India Precambrian Res 267 164-173

Ishwar-Kumar C, Windley B F, Horie K, Kato T, Hokada T, Itaya T, Yagi K, Gouzu C and Sajeev K (2013) A Rodinian suture in western India: New insights on India-Madagascar correlations Precambrian Res 236 227-251

Jayananda M, Chardon D, Peucat J J and Tushipokla Fanning C M (2015) Paleo- to Mesoarchean TTG accretion and continental growth in the western Dharwar craton, Southern India: Constraints from SHRIMP U-Pb zircon geochronology, whole-rock geochemistry and Nd-Sr isotopes Precambrian Res 268 295-322

Jayananda M, Peucat J J, Chardon D, Rao B K, Fanning C M and Corfu F (2013a) Neoarchean greenstone volcanism and continental growth, Dharwar craton, southern India: Constraints from SIMS U-Pb zircon geochronology and Nd isotopes Precambrian Res 227 55-76

Jayananda M, Tsutsumi Y, Miyazaki T, Gireesh R V, Kapfo K U, Tushipokla Hidaka $\mathrm{H}$ and Kano $\mathrm{T}$ (2013b) Geochronological constraints on Meso- and Neoarchean regional metamorphism and magmatism in the Dharwar craton, southern India J Asian Earth Sci 78 18-38

Johnson T E, Clark C, Taylor R J M, Santosh M and Collins A S (2015) Prograde and retrograde growth of monazite in migmatites: An example from the Nagercoil Block, southern India Geosci Front 6 373-387

Joy S, Jelsma H, Tappe S and Armstrong R (2015) SHRIMP U$\mathrm{Pb}$ zircon provenance of the Sullavai Group of PranhitaGodavari Basin and Bairenkonda Quartzite of Cuddapah
Basin, with implications for the Southern Indian Proterozoic tectonic architecture J Asian Earth Sci 111 827-839

Karmalkar N R, Duraiswami R A, Jonnalagadda M K and Griffin W L (2014) Mid-Cretaceous lamproite from the Kutch region, Gujarat, India: Genesis and tectonic implications Gondwana Res 26 942-956

Kaur P, Chaudhri N, Hofmann A W, Raczek I and Okrusch M (2013) Geochemistry and Sm-Nd geochronology of the metasomatised mafic rocks in the Khetri complex, Rajasthan, NW India: Evidence of an Early Cryogenian metasomatic event in the northern Aravalli orogen J Asian Earth Sci 62 401-413

Koizumi T, Tsunogae T, Santosh M, Tsutsumi Y, Chetty T R K and Saitoh Y (2014) Petrology and zircon U-Pb geochronology of metagabbros from a mafic-ultramafic suite at Aniyapuram: Neoarchean to Early Paleoproterozoic convergent margin magmatism and Middle Neoproterozoic high-grade metamorphism in southern India J Asian Earth Sci 95 51-64

Korhonen F J, Clark C, Brown M, Bhattacharya S and Taylor R (2013) How long-lived is ultrahigh temperature (UHT) metamorphism? Constraints from zircon and monazite geochronology in the Eastern Ghats orogenic belt, India Precambrian Res 234322 -350

Kröner A and Liu D (2012) Advances in high-resolution ionmicroprobe geochronology Gondwana Res 21 717-718

Kröner A, Santosh M, Hegner E, Shaji E, Geng H, Wong J, Xie H, Wan Y, Shang C K, Liu D, Sun M and Nanda-Kumar V (2015) Palaeoproterozoic ancestry of Pan-African highgrade granitoids in southernmost India: Implications for Gondwana reconstructions Gondwana Res 27 1-37

Kröner A, Santosh M and Wong J (2012) Zircon ages and Hf isotopic systematics reveal vestiges of Mesoproterozoic to Archaean crust within the late Neoproterozoic-Cambrian high-grade terrain of southernmost India Gondwana Res 21 876-886

Kumar A, Parashuramulu V and Nagaraju E (2015) A $2082 \mathrm{Ma}$ radiating dyke swarm in the Eastern Dharwar Craton, southern India and its implications to Cuddapah basin formation Precambrian Res 266 0-16

Kumar A, Nagaraju E, Srinivasa Sarma D and Davis D W (2014) Precise $\mathrm{Pb}$ baddeleyite geochronology by the thermal extraction-thermal ionization mass spectrometry method Chem Geol 372 72-79

Kumar A, Nagaraju E, Besse J, Rao Y J and Bhaskar Rao (2012) New age, geochemical and paleomagnetic data on a $2.21 \mathrm{Ga}$ dyke swarm from south India: Constraints on 
Paleoproterozoic reconstruction Precambrian Res 220221 123-138

Lancaster P J, Dey S, Storey C D, Mitra A and Bhunia R K (2015) Contrasting crustal evolution processes in the Dharwar craton: Insights from detrital zircon $\mathrm{U}-\mathrm{Pb}$ and $\mathrm{Hf}$ isotopes Gondwana Res 28 1361-1372

Liu D Y, Wan Y S, Wu J S, Wilde S A, Zhou H Y, Dong C Y and Yin X Y (2007) Eoarchean rocks and zircons in the North China craton. In: Van Kranendonk M J, Smithies R H, Bennett V C (Eds.), Earth's Oldest Rocks, in: Developments in Precambrian Geology. Elsevier, Amsterdam, 251-273

Maibam B, Gerdes A and Goswami J N (2016) U-Pb and Hf isotope records in detrital and magmatic zircon from eastern and western Dharwar craton, southern India: Evidence for coeval Archaean crustal evolution Precambrian Res 275 496-512

Maibam B, Sanyal P and Bhattacharya S (2015) Geochronological Study of Metasediments and Carbon Isotopes in Associated Graphites from the Sargur Area, Dharwar Craton/ : Constraints on the Age and Nature of the Protoliths J Geol Soc India $\mathbf{8 5}$ 577-585

McKenzie N R, Hughes N C, Myrow P M, Banerjee D M, Deb M and Planavsky N J (2013) New age constraints for the Proterozoic Aravalli-Delhi successions of India and their implications Precambrian Res 238 120-128

Meert J G, Pandit M K and Kamenov G D (2013) Further geochronological and paleomagnetic constraints on Malani (and pre-Malani) magmatism in NW India Tectonophysics 608 1254-1267

Mohan M R, Sarma D S, McNaughton N J, Fletcher I R, Wilde S A, Siddiqui M A, Rasmussen B, Krapez B, Gregory C J and Kamo S L (2014) SHRIMP zircon and titanite U-Pb ages, Lu-Hf isotope signatures and geochemical constraints for $2.56 \mathrm{Ga}$ granitic magmatism in Western Dharwar Craton, Southern India: Evidence for short-lived Neoarchean episodic crustal growth Precambrian Res $\mathbf{2 4 3}$ 197-220

Mohan M R, Satyanarayanan M, Santosh M, Sylvester P J, Tubrett M and Lam R (2013) Neoarchean suprasubduction zone arc magmatism in southern India: Geochemistry, zircon $\mathrm{U}-\mathrm{Pb}$ geochronology and $\mathrm{Hf}$ isotopes of the Sittampundi Anorthosite Complex Gondwana Res 23 539-557

Mohanty D P and Chetty T R K (2014) Possible detachment zone in Precambrian rocks of Kanjamalai Hills, Cauvery Suture Zone, Southern India: Implications to accretionary tectonics J Asian Earth Sci 88 50-61

Mojzsis S J and Harrison T M (2002) Establishment of a 3.83 Ga magmatic age for the Akilia tonalite (southern West Greenland) Earth Planet Sci Lett 202 563-576

Mojzsis S J, Cates N L, Caro G, Trail D, Abramov O, Guitreau M, Blichert-Toft J, Hopkins M D and Bleeker W (2014) Component geochronology in the polyphase ca. 3920Ma Acasta Gneiss Geochim Cosmochim Acta 133 68-96

Mukherjee R, Mondal S K, Frei R, Rosing M T, Waight T E, Zhong H and Kumar G R R (2012) The 3.1Ga Nuggihalli chromite deposits, Western Dharwar craton (India): Geochemical and isotopic constraints on mantle sources, crustal evolution and implications for supercontinent formation and ore mineralization Lithos 155 392-409

Mukhopadhyay J, Beukes N J, Armstrong R A, Zimmermann U, Ghosh G and Medda R A (2008) Dating the oldest Greenstone in India, a 3.51-Ga precise $\mathrm{U}-\mathrm{Pb}$ SHRIMPzircon age for Dacitic Lava of the Southern Iron Ore Group, Singhbhum Craton J Geol 116 449-461

Naqvi S M (2005) Geology and Evolution of the Indian Plate (From Hadean to Holocene-4 Ga to $4 \mathrm{Ka}$ ) $\mathrm{Ca} \mathrm{Publ}$ Company New Delhi 450

Nelson D R, Bhattacharya H N, Thern E R and Altermann W (2014) Geochemical and ion-microprobe U-Pb zircon constraints on the Archaean evolution of Singhbhum Craton, eastern India Precambrian Res 255 412-432

Noack N M, Kleinschrodt R, Kirchenbaur M, Fonseca R O C and Münker C (2013) Lu-Hf isotope evidence for Paleoproterozoic metamorphism and deformation of Archean oceanic crust along the Dharwar Craton margin, southern India Precambrian Res 233 206-222

Nutman A, McGregor V and Friend C (1996) The Itsaq Gneiss Complex of southern West Greenland/ ; the world's most extensive record of early crustal evolution Precambrian Res 78 1-39

O’Neil J, Maurice C, Stevenson R K, Larocque J, Cloquet C, David J, Francis D, Martin J, Van Kranendonk R S H and Vickie C B (2007) The geology of 3.8 Ga Nuvvuagittuq (Porpoise Cove) greenstone belt, Northeastern Superior Province, Canada., in: Developments in Precambrian Geology Elsevier 219-250

Ozha M K, Mishra B, Hazarika P, Jeyagopal A V and Yadav G S (2016) EPMA monazite geochronology of the basement and supracrustal rocks within the Pur-Banera basin, Rajasthan: Evidence of Columbia breakup in Northwestern India J Asian Earth Sci 117 284-303

Pandey U K, Sastry D V L N, Pandey B K, Roy M, Rawat T P S, Ranjan R and Shrivastava V K (2012) Geochronological ( $\mathrm{Rb}-\mathrm{Sr}$ and $\mathrm{Sm}-\mathrm{Nd}$ ) studies on intrusive gabbros and dolerite dykes from parts of northern and central Indian cratons: 
Implications for the age of onset of sedimentation in Bijawar and Chattisgarh basins and uranium mineralisation $\mathrm{J} \mathrm{Geol}$ Soc India 79 30-40

Pease V, Percival J, Smithies H, Stevens G and Kranendonk M Van (2008) When did plate tectonics begin/ ? Evidence from the orogenic record, 199-228

Peucat J J, Jayananda M, Chardon D, Capdevila R, Fanning M M and Paquette J L (2013) The lower crust of the Dharwar Craton, Southern India: Patchwork of Archean granulitic domains Precambrian Res 227 4-28

Pisarevsky S A, Biswal T K, Wang X C, De Waele B, Ernst R, Soderlund U, Tait J A, Ratre K, Singh Y K and Cleve M (2013) Palaeomagnetic, geochronological and geochemical study of Mesoproterozoic Lakhna Dykes in the Bastar Craton, India: Implications for the Mesoproterozoic supercontinent Lithos 174 125-143

Plavsa D, Collins AS, Foden J D and Clark C (2015) The evolution of a Gondwanan collisional orogen: A structural and geochronological appraisal from the Southern Granulite Terrane, South India Tectonics 34 820-857

Plavsa D, Collins A S, Foden J F, Kropinski L, Santosh M, Chetty T R K and Clark C (2012) Delineating crustal domains in Peninsular India: Age and chemistry of orthopyroxene-bearing felsic gneisses in the Madurai Block Precambrian Res 198 77-93

Prabhakar N and Bhattacharya A (2013) Paleoarchean partial convective overturn in the Singhbhum Craton, Eastern India Precambrian Res 231 106-121

Pradhan V R, Meert J G, Pandit M K, Kamenov G and Mondal MEA(2012) Paleomagnetic and geochronological studies of the mafic dyke swarms of Bundelkhand craton, central India: Implications for the tectonic evolution and paleogeographic reconstructions Precambrian Res 198 5176

Praveen M N, Santosh M, Yang Q Y, Zhang Z C, Huang H, Singanenjam S and Sajinkumar K S (2014) Zircon U-Pb geochronology and $\mathrm{Hf}$ isotope of felsic volcanics from Attappadi, southern India: Implications for Neoarchean convergent margin tectonics Gondwana Res 26 907-924

Purohit R, Papineau D, Kroner A, Sharma K K and Roy A B (2012) Carbon isotope geochemistry and geochronological constraints of the Neoproterozoic Sirohi Group from northwest India Precambrian Res 220 80-90

Rai A K, Pandey U K, Zakaulla S and Parihar P S (2015) New 1.9-2.0 Ga, $\mathrm{Pb}-\mathrm{Pb}$ (PbSL), Age of Dolomites from Vempalle Formation, Lower Cuddapah Supergroup, Eastern Dharwar Craton, India J Geol Soc India 86 131-136

Raith M M, Mahapatro S N, Upadhyay D, Berndt J, Mezger K and Nanda J K (2014) Age and P-T evolution of the Neoproterozoic Turkel Anorthosite Complex, Eastern Ghats Province, India Precambrian Res 254 87-113

Rajesh H M (2012) A geochemical perspective on charnockite magmatism in Peninsular India Geosci Front 3 773-788

Rajgopal A (2012) Evolution of the Eastern Dharwar craton from the Perspective of New Isotope Data from the Hutti Greenstone-Granite terrane - Anand Rajgopal, Geological Survey of India , Bangalore Response of the Rivers in Himalaya to Late Pleistocene-Holocene Climate and $J$ Geol Soc India 79 541-542

Ramakrishnan M and Vaidyanadhan R (2008) Geology of India J Geol Soc India 1994

Rao D C V, Santosh M and Kim S W (2012) Cryogenian volcanic arc in the NW Indian Shield: Zircon SHRIMP U-Pb geochronology of felsic tuffs and implications for Gondwana assembly Gondwana Res 22 36-53

Rao C V D, Santosh M and Zhang S H (2014) Neoproterozoic massif-type anorthosites and related magmatic suites from the Eastern Ghats Belt, India: Implications for slab window magmatism at the terminal stage of collisional orogeny Precambrian Res 240 60-78

Rao N V C, Wu F Y, Mitchell R H, Li Q L and Lehmann B (2013) Mesoproterozoic $\mathrm{U}-\mathrm{Pb}$ ages, trace element and $\mathrm{Sr}-\mathrm{Nd}$ isotopic composition of perovskite from kimberlites of the Eastern Dharwar craton, southern India: Distinct mantle sources and a widespread $1.1 \mathrm{Ga}$ tectonomagmatic event Chem Geol 353 48-64

Rekha S, Bhattacharya A and Chatterjee N (2014) Tectonic restoration of the Precambrian crystalline rocks along the west coast of India: Correlation with eastern Madagascar in East Gondwana Precambrian Res 252 191-208

Renjith M L, Santosh M, Li T, Satyanarayanan M, Korakoppa M M, Tsunogae T, Subba Rao D V, Kesav Krishna A and Nirmal Charan S (2016) Zircon U-Pb age, Lu-Hf isotope, mineral chemistry and geochemistry of Sundamalai peralkaline pluton from the Salem Block, southern India: Implications for Cryogenian adakite-like magmatism in an aborted-rift J Asian Earth Sci 115 321-344

Ravikant V, Shakil H, Chatterjee C, Ji W Q and Wu F Y (2014) Initiation of the intra-cratonic Cuddapah basin: evidence from Paleoproterozoic (1995 Ma) anorogenic porphyritic granite in Eastern Dharwar Craton basement J Asian Earth Sci 79 235-245

Roy A B, Kroner A, Rathore S, Laul V and Purohit R (2012) Tectono-metamorphic and geochronologic studies from Sandmata complex, northwest Indian shield: Implications on exhumation of late-Palaeoproterozoic granulites in an 
Archaean-early Palaeoproterozoic granite-gneiss terrane $J$ Geol Soc India 79 323-334

Saha D and Patranabis-Deb S (2014) Proterozoic evolution of eastern dharwar and bastar cratons, India - An overview of the intracratonic basins, craton margins and mobile belts $J$ Asian Earth Sci 91 230-251

Samuel V O, Sajeev K, Hokada T, Horie K and Itaya T (2014a) Neoarchean arc magmatism followed by high-temperature, high-pressure metamorphism in the Nilgiri Block, southern India Tectonophysics 662 109-104

Samuel V O, Santosh M, Liu S, Wang W and Sajeev K (2014b) Neoarchean continental growth through arc magmatism in the Nilgiri Block, southern India Precambrian Res $\mathbf{2 4 5}$ 146-173

Santosh M, Shaji E, Tsunogae T, Ram Mohan M, Satyanarayanan $M$ and Horie K (2013) Suprasubduction zone ophiolite from Agali hill: Petrology, zircon SHRIMP U-Pb geochronology, geochemistry and implications for Neoarchean plate tectonics in southern India Precambrian Res 231 301-324

Santosh M, Xiao W J, Tsunogae T, Chetty T R K and Yellappa T (2012) The Neoproterozoic subduction complex in southern India: SIMS zircon U-Pb ages and implications for Gondwana assembly Precambrian Res 192 190-208

Santosh M, Yang Q Y, Ram Mohan M, Tsunogae T, Shaji E and Satyanarayanan M (2014) Cryogenian alkaline magmatism in the Southern Granulite Terrane, India: Petrology, geochemistry, zircon $\mathrm{U}-\mathrm{Pb}$ ages and $\mathrm{Lu}-\mathrm{Hf}$ isotopes Lithos 208 430-445

Santosh M, Yang Q Y, Shaji E, Mohan M R, Tsunogae T and Satyanarayanan M (2016) Oldest rocks from Peninsular India: Evidence for Hadean to Neoarchean crustal evolution Gondwana Res 29 105-135

Santosh M, Yang Q Y, Shaji E, Tsunogae T, Mohan M R and Satyanarayanan M (2015) An exotic Mesoarchean microcontinent: The Coorg Block, southern India Gondwana Res 27 165-195

Sarkar S C and Gupta A (2012) Crustal Evolution and Metallogeny in India Cambridge Univ Press Delhi 912

Sarkar T, Schenk V, Appel P, Berndt J and Sengupta P (2014) Two-stage granulite formation in a Proterozoic magmatic arc (Ongole domain of the Eastern Ghats Belt, India): Part 2. LA-ICP-MS zircon dating and texturally controlled insitu monazite dating Precambrian Res 255 467-484

Sarma R S (2010) Cratons and Fold Belts of India SpringerVerlag Berlin Heidelberg 304

Shaji E, Santosh M, He X F, Fan H R, Dev S G D, Yang K F, Thangal M K and Pradeepkumar A P (2014) Convergent margin processes during Archean-Proterozoic transition in Southern India: Geochemistry and zircon $\mathrm{U}-\mathrm{Pb}$ geochronology of gold-bearing amphibolites, associated metagabbros, and TTG gneisses from Nilambur Precambrian Res $25068-96$

Shankar R, Vijaya Gopal B and Anil Kumar (2014) Precise Pb-Pb baddeleyite ages of 1765 Ma for a Singhbhum 'newer dolerite' dyke swarm Current Science 106 1306-1310

Shazia J R, Harlov D E, Suzuki K, Kim S W, Girish-Kumar M, Hayasaka Y, Ishwar-Kumar C, Windley B F and Sajeev K (2015) Linking monazite geochronology with fluid infiltration and metamorphic histories: Nature and experiment Lithos 236 1-15

Shimojo M, Yamamoto S, Sakata S, Yokoyama T D, Maki K, Sawaki Y, Ishikawa A, Aoki K, Aoki S, Koshida K, Tashiro T, Hirata T, Collerson K D and Komiya T (2016) Occurrence and geochronology of the Eoarchean, $3.9 \mathrm{Ga}$, Iqaluk Gneiss in the Saglek Block, northern Labrador, Canada: Evidence for the oldest supracrustal rocks in the world Precambrian Res 278 218-243

Srivastava R K and Gautam G C (2015) Geochemistry and petrogenesis of Paleo - Mesoproterozoic mafi c dyke swarms from northern Bastar craton, central India: Geodynamic implications in reference to Columbia supercontinent Gondwana Res 28 1061-1078

Srivastava S K, Hamilton S, Nayak S, Pandey U K, Mohanty R and Umamaheswar K (2015) Petrography , Geochemistry and $\mathrm{Rb}-\mathrm{Sr}$ Geochronology of the Basement Granitoids from Umthongkut Area, West Khasi Hills District, Meghalaya, India/ : Implications on Petrogenesis and Uranium Mineralization J Geol Soc India 86 59-70

Tachikawa K and Elderfield H (2002) Establishment of a 3.83-Ga magmatic age for the Akilia tonalite (southern West Greenland) Earth Planet Sci Lett 202 563-576

Taylor R J M, Clark C, Johnson T E, Santosh M and Collins A S (2015) Unravelling the complexities in high-grade rocks using multiple techniques - the Achankovil Zone of southern India Contrib to Mineral Petrol 165

Tomson J K, Bhaskar Rao Y J, Vijaya Kumar T and Choudhary A K (2013) Geochemistry and neodymium model ages of Precambrian charnockites, Southern Granulite Terrain, India: Constraints on terrain assembly Precambrian Res 227 295-315

Trail D, Watson E B and Tailby N D (2013) Insights into the Hadean Earth from experimental studies of zircon $J$ Geol Soc India 81 605-636

Tripathy G R and Singh S K (2015) Re-Os depositional age for black shales from the Kaimur Group, Upper Vindhyan, 
India Chem Geol 413 63-72

Tripathy G R, Singh S K and Bhu H (2013) Re-Os isotopes and major and trace element geochemistry of carbonaceous shales, Aravalli Supergroup, India: Impact of postdepositional processes Chem Geol 354 93-106

Turner C C, Meert J G, Pandit M K and Kamenov G D (2014) A detrital zircon $\mathrm{U}-\mathrm{Pb}$ and $\mathrm{Hf}$ isotopic transect across the Son Valley sector of the Vindhyan Basin, India: Implications for basin evolution and paleogeography Gondwana Res 26 348-364

Tushipokla Jayananda M (2013) Geochemical constraints on komatiite volcanism from Sargur Group Nagamangala greenstone belt, western Dharwar craton, southern India: Implications for Mesoarchean mantle evolution and continental growth Geosci Front 4 321-340

Upadhyay D, Chattopadhyay S, Kooijman E, Mezger K and Berndt J (2014) Magmatic and metamorphic history of Paleoarchean tonalite-trondhjemite-granodiorite (TTG) suite from the Singhbhum craton, eastern India Precambrian Res 252 180-190

Valdiya K S (2010) The Making of India: Geodynamic Evolution Macmillan Publ 816

Venkateshwarlu M and Chalapathi Rao N V (2013) New palaeomagnetic and rock magnetic results on Mesoproterozoic kimberlites from the Eastern Dharwar craton, southern India: Towards constraining India's position in Rodinia Precambrian Res 224 588-596

Verma S K, Verma S P, Oliveira E P, Singh V K and Moreno J A (2016) LA-SF-ICP-MS zircon U-Pb geochronology of granitic rocks from the central Bundelkhand greenstone complex, Bundelkhand craton, India J Asian Earth Sci 118 125-137

Vijaya Kumar T, Bhaskar Rao Y J, Diana Plavsa Alan S Collins, Tomson J K, Vijaya Gopal B, Babu E V S S K, Zircon U$\mathrm{Pb}$ ages and $\mathrm{Hf}$ isotopic systematics of charnockite gneisses from the Ediacaran-Cambrian high-grade metamorphic terrains, southern India: constraints on crust formation, recycling and Gondwana correlations Bull Geol Soc Am (Under Revision)
Voice P J, Kowalewski M and Eriksson K (2011) Quantifying the timing and rate of crustal evolution: Global compilation of radiometrically dated detrital zircon grains J Geol 119 109-126

Wilde S A, Valley J W, Peck W H and Graham C M (2001) Evidence from detrital zircons for the existence of continental crust and oceans on the Earth 4.4 Gyr ago Nature 409 175-178

Yang Q Y and Santosh M (2015) Zircon U-Pb geochronology and Lu-Hf isotopes from the Kolar greenstone belt, Dharwar Craton, India: Implications for crustal evolution in an ocean-trench-continent transect J Asian Earth Sci 113797 811

Yang Q Y, Santosh M, Pradeepkumar A P, Shaji E, Prasanth R S and Dev S G D (2015) Crustal evolution in the western margin of the Nilgiri Block, southern India: Insights from zircon U-Pb and Lu-Hf data on Neoarchean magmatic suite J Asian Earth Sci 113 766-777.

Yellappa T, Santosh M, Chetty T R K, Kwon S, Park C, Nagesh P, Mohanty D P and Venkatasivappa V (2012) A Neoarchean dismembered ophiolite complex from southern India: Geochemical and geochronological constraints on its suprasubduction origin Gondwana Res 21 246-265

Zhang Z, Xiang H, Dong X, Ding H and He Z (2015) Long-lived high-temperature granulite-facies metamorphism in the Eastern Himalayan orogen, south Tibet Lithos 212 1-15

Zhou J L, Shao S, Luo Z H, Shao J B, Wu D T and Rasoamalala V (2015) Geochronology and geochemistry of Cryogenian gabbros from the Ambatondrazaka area, east-central Madagascar: Implications for Madagascar-India correlation and Rodinia paleogeography Precambrian Res 256 256270

Zhuang G, Najman Y, Guillot S, Roddaz M, Antoine P O, Metais G, Carter A, Marivaux L and Solangi S H (2015) Constraints on the collision and the pre-collision tectonic configuration between India and Asia from detrital geochronology, thermochronology, and geochemistry studies in the lower Indus basin, Pakistan Earth Planet Sci Lett 432 363-373. 